\title{
Chara globata Mig. (Streptophyta: Charales): rare species revised
}

\author{
Roman E. Romanov ${ }^{1 *}$, Andrey A. Gontcharov ${ }^{2} \&$ Sophia S. Barinova ${ }^{3}$
}

\author{
${ }^{I}$ Central Siberian Botanical Garden, Siberian Branch of the Russian Academy of Sciences, Zolotodolinskaya \\ 101, 630090 Novosibirsk, Russia; *Corresponding author e-mail: romanov_r_e@ngs.ru \\ ${ }^{2}$ Institute of Biology and Soil Science, Far Eastern Branch of the Russian Academy of Sciences, 690022 \\ Vladivostok, Russia \\ ${ }^{3}$ Institute of Evolution, University of Haifa, Mount Carmel, 3498838 Haifa, Israel
}

\begin{abstract}
A rare species Chara globata Mig. has a distinct habit and may be referred to as a flagship species. Here we describe a wide range of vegetative and reproductive morphologies in C. globata in localities distant from the locus classicus. In contrast to the known holotype features, the specimens studied consistently displayed a generally tylacanthous diplostichous stem cortex which is in agreement with protologue. Based on morphology, phylogenetic affinity (this study) and results of breeding experiments (PROCTOR 1971, 1975), we proposed that $C$. globata should be transferred to the section Chara. Current data suggest that C. globata is a species with a disjunctive distribution, mainly in the arid and semiarid regions of Eurasia. Specimens collected from the end of the 1960s to the beginning of the 1970s confirmed the existence C. globata in Western Asia. The species was also recorded in Europe and the Sahara-Arabian Desert for the first time.
\end{abstract}

Key worlds: Chara globata, charophytes, distribution, ecology, morphology, oospores, phylogeny, taxonomy

\section{INTRODUCTION}

Eighty-one extant macrospecies and nearly 395 microspecies of charophytes that have been described to date are classified according to the morphospecies concept (WOOD \& IMAHORI 1965). Although some of these microspecies are frequently listed in regional checklists and floras, many others are rarely mentioned in the literature. This may reflect an absence of the species in the region studied, as well as their misidentification or unrepresentative sampling. A few large- and medium-sized charophytes have distinct habits, which makes it almost impossible to overlook these species within the charophyte collection, meaning that these species could be referred to as flagship species: "Flagships are so showy, or so novel, making it unlikely that they would be overlooked" (FoISSNER et al. 2008: 117). This concept is a useful tool for the biogeography of protists and microalgae (TYLER 1996; FOISSNER 2006) and can probably be applied to other groups of living organisms. The scarcity of records for flagship species likely reflects their extreme rarity or probable absence in the extensively studied regions. Chara globata Mig. is one of such a species, having distinct habit, resembling Lychnothamnus (Migula 1904; Wood \& IMAHORI 1964, 1965) or Chara vertillibracteata Y.J. WANG et W.T. Su in W.T. Su et al. (HAN \& Li 1994).

Chara globata has been rarely reported since its initial description (Migula 1904; Wood 1952, 1959, 1962, 1964; WoOd \& IMAHORI 1959, 1964, 1965;
Bicudo 1976; Soulie-MäRSCHE 1989). It is known from eastern, northwestern and southwestern China (MigULA 1904; Han \& Li 1994; Deng \& Zhang 1996; LiNG et al. 2000), southern Kazakhstan (Kostin \& SHOYAKUBOV 1972 1973a,b, 1974a,b; Shoyakubov 1973, 1979) and Israel (Milner \& Avigad 1972; Brimacombe et al. 1973). C. globata was used in breeding experiments for taxonomic purposes and for tests of the applicability of the biological species concept to charophytes (PROCTOR 1971, 1975).

Morphological descriptions and illustrations of C. globata are based on the re-examined holotype only. Phenotypic characteristic of C. globata remain incomplete due to limited information about oospore morphology and range of morphological variability. The morphological descriptions, distributional records, and habitat characteristics of C. globata are scarce and require supplementation and improvement. $C$. globata has been assigned to the section Grovesia R.D. WooD, subsection Grovesia R.D. Wood (Wood 1962, 1964; Wood \& IMAHORI 1965) and section Diplostephanae, series or subsection Triplostichae (HAN \& LI 1994; LiNG et al. 2000). However, these placements were not supported by results of breeding experiments, that instead pointed towards its affinity with members of section Chara, subsection Hartmania R.D. Wood (Proctor 1971, 1975). An improvement in C. globata description is needed for clarification of its taxonomic and phylogenetic affinities within the genus, as for many charophyte species.

Here we aimed to study the morphology and 
molecular phylogenetic affinity of rare species $C$. globata based on the specimens collected in localities distant from locus classicus.

\section{Materials and Methods}

reparations and study of specimens. Nineteen herbariun sheets labeled as Chara globata were found during examination of the Israeli charophytes collection stored in Tel Aviv University Herbarium - TELA (Romanov \& BARINOVA 2012). The specimens were collected by E. CoHeN,
Y. LIPKIN, and W. Proctor in 1969 and 1970 in Israel and Y. LIPKIN, and W. PROCTOR in 1969 and 1970 in Israel and Egypt. Recently, A.N. LuBCHENKo revealed a population of $C$.
globata on the southern European part of Russia and kindly globata on the southern European part of Russia and kindly
sampled it at our request. These specimens were deposited in the NS (Herbarium of Central Siberian Botanical Garden SB RAS). Altogether, 26 herbarium sheets were examined.

Specimens were treated according to Hollerbach \& Krasavina (1983). The photos were taken with a Carl Zeis Stereo Discovery V12 stereomicroscope equipped with an
AxioCam MRs- 5 digital camera. The terms "differentiated" AxioCam MRs-5 digital camera. The terms "differentiated" part with and without nodes (Frame 1974). Consequently, the formation of a cortex and bract-cells or only bract-cells ha been assumed as indicators of the formation of nodes within branchlets.

The oospores were treated with acetic acid to remove any lime-shell, washed with distilled water and cleaned from spiral cells by adding $10 \%$ Triton X100, then stored at $60^{\circ} \mathrm{C}$ for at least 10 hours. Finally, they were washed with distilled cleaned oospores were stored in $95 \%$ alcohol. They were coated with zinc and studied with a scanning electron microscope ZEISS EVO 40 (Carl Zeiss) at $17.54 \mathrm{kV}$. The erms used for describing the oospore surface followed those from URBANIAK (2011). All photos were digitally manipulated and plates were created using Adobe Photoshop 8.0®. The DNA was extracted with the modified Echt's method (Echt et al. 1992; KIsELEv et al. 2011) from the specimens collected in the Maagan Michael Quarry (Israel) of specimens were allowed to detach from several apica parts of thalli without obvious deterioration. A partial rbcL gene was amplified with primers RH1 and 1385R (MANHART et al. 1994), and PCR products were directly sequenced using the ABI Big Dye Terminator v.3.1 Cycle Sequencing kit according to the manufacturer's instructions and the $\mathrm{AB}$ 3130 genetic analyzer at the Institute of Biology and Soil
Science FEB RAS. The resulting sequences were submitted Science FEB RAS. The resulting sequences were submitted numbers: LM653113 (TELA: 20373) and LM653114 (NS: 500 )

To assess the phylogenetic relationship of $C$. globata we assembled a data set including putatively related $C$ hispida (L.) HARTM. (HF912657), C. intermedia A. BRAUN (HF912656), C. rudis A. Braun in Leonh. (HF912655), C. baltica Bruzeluss (HF912653), C. polyacantha A. Braun in A. Braun, Rabenh. et Stizenb. (AY170453), C (HF912646) C vulgaris L (DQ229107), C. aspera Willd. (HF912645), C. connivens SAlzM, ex A. BradN (HF912648, AF097161, L13476, AF097162), C virgata Kǘtz. (HF912649), C. globularis THuLL. (AB440244,
AF097163, HF912647, F097164), C. canescens Desv. et LoIsel. in Loisel. (AM710330), C. fibrosa C. Agardh ex BRUzELUUS (AB359168), C. zeylanica KLeEN ex WILLD. en R.D. Wood (AB359169), C. rusbyana M. Howe (AF097168),

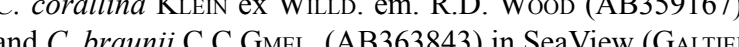
et al. 1996) and analyzed with Maximum Parsimony metho in PAUP* 4.0 b10 (SwOFFord 2002) by a heuristic search with tree-bisection-reconnection (TBR) branch swapping and 10 random sequence addition replicates. The support for branches was calculated by bootstrap analyses with 1000 eplications of heuristic search.

\section{Results and Discussion}

\section{Morphology}

\section{Existing morphological descriptions}

Chara globata MIG.

Migula 1904: 537, 538; Wood \& IMAHORI 1964: Icone 87; Woo \& ІмАнові

C. globata was initially described as a monoeciou diplostephanous diplostichous slightly tylacanthous species with corticated branchlets with 1 to 2-celled ecorticate segments, and conjoined gametangia; an occupying a distinct habit due to its peculiar clenched like whorls of branchlets with long bract-cells an bracteoles (MigULA 1904). It should be emphasized that stem cortex arrangement according to protologue MiguLA 1904) contrasts the later description of holotype (WOOD \& IMAHORI 1964, 1965; HAN \& L 1994), reporting irregular (haplo-diplo)-triplostichous isostichous cortex. This discrepancy may reflect the differences in the studied material with the descriptio by WOOD \& IMAHORI $(1964,1965)$ being based on single broken specimen consisting of four fertile head and one main axis. Unfortunately the type specime was lost and the only currently available paratype is stored in LE (Fig. Sla). These paratype specimens have a slightly tylacanthous and isostichous stem cortex.

he description in the "Flora Algarum Sinicarum Aquae-Dulcis" repeats the holotype description (cf. WOOD \& IMAHORI 1965; HAN \& LI 1994). It could be that specimens collected in China from localities other than locus classicus fitted the existing description, or that they were not described. Later Chinese specimen of C. globata were described as monoecious wit irregular triplostichous tylacanthous cortex, solitary spine cells, developed stipulodes, 6 branchlet segments, $5-6$ developed bract-cells, and conjoined gametangia (Ling et al. 2000)

Morphological description of studied specimen The degree of incrustation varies in specimens from different localities (for details see S1); from calciteunencrusted with slightly encrusted old parts to the moderately and heavily incrusted. Two forms of growth are presented in the collections. The first one is a medium-sized tufted plant, up to $18 \mathrm{~cm}$ in height consisting of numerous stems emerging from the common tangle of rhizoids. The more common varian is a medium- or large-sized shoot herbarized alone (Fig. SI) or as a bunch of partially entangled stems, with the lowest parts decaying. The maximal size of vailable fragments is $64.5 \mathrm{~cm}$ recorded in oxbow lake and 75.5 to $99 \mathrm{~cm}$ in Solomon's pools.

The stems are mostly stout, from 435-793(858) to $1500 \mu \mathrm{m}$ in diameter. The internodes in the apical parts are up to 2-times shorter than branchlets or several times longer in strongly elongated plants, and usually longer than the branchlets within other parts of the thallus. The upper parts of non-suppressed thalli look like spherical loose heads due to their short upper internodes and dense long bract-cells (Figs 1a, S1a-c).

The stem cortex is diplostichous, moderately or slightly but distinctly tylacanthous, sometimes isostichous (Fig. 1b-d). The regular, slightly tylacanthous triplostichous cortex is rarely formed. Although a diplostichous cortex prevails, diplotriplostichous patches and triplostichous cortexes do occur. The stem spine-cells are solitary only, squarrose at right angles to the stem, acute, with distinctly thickened cell walls at their ends, and variable in length from short conical-papillose to conical and long subulate (Fig. 1b-d).

The stipulodes are in two tiers two sets per branchlet, and long aculeiform with acute ends (Fig. le). The branchlets are usually straight, slightly arcuate or very rarely reflexed, 9-11 in a whorl, 1.6-3.9(4.2) $\mathrm{cm}$ in length, and 300-510 $\mu \mathrm{m}$ in diameter (Fig. 1a, f). The branchlet consists of $0-1-6$ completely corticated segments and with an ecorticate segment of variable length that consists of a variable number of cells (having an inverse relationships with the corticated segment's number). The branchlets in non-suppressed plants are completely or nearly completely differentiated (i.e., have regularly formed nodes), which could be easily revealed by the presence of conspicuous bractcells (Fig. 1g). The branchlet cortex is completely diplostichous.

The bract-cells are subulate with distinctly thickened acute ends, distinctly verticillate, up to 4.5 $\mathrm{mm}$ in length, and slightly posteriors or 1.8-3-time shorter than the anteriors (Fig. 1a, f-i). The length of the bract-cells is variable. The exact differentiation of the specimens originating from different localities on the basis of the relative lengths of their bract-cells is almost impossible due to the overlapping of extreme values of this feature.

The gametangia are solitary, conjoined, occurring at the 2-4 lowest nodes between corticated segments (Fig. Th) and between ecorticate segments in a single case only (Fig. 1i). The antheridia are octoscutate.

The abundance of ripe oospores is low or they are absent in the majority of specimens. The ripe oospores are black in reflective and transmitted light. The oospores have 11-14 striae of moderate height, ending at the base of the oospores with basket-like protrusions, which surround the basal plate (Fig. 2a b). The oospores are $745-881 \mu \mathrm{m}$ (incl. protrusions) or $652-776 \mu \mathrm{m}$ (excl. protrusions) in length and (303)343$503 \mu \mathrm{m}$ in width. The oospore ornamentation varie from nearly smooth and indistinctly pustular through pustular to papillate (Fig. 2c, d). The ornamentation of the fossa and ribs are identical.

Comparison of existing morphological descriptions The stem cortex arrangement of studied specimens is in agreement with the protologue of C. globata (MiguLA 1904) and description of other Chinese specimen (Ling et al. 2000). Our specimens differed from the diagnosis based on holotype re-examination (WOOD \& IMAHORI 1964,1965$)$ in the following features:

1) Generally, a tylacanthous diplostichous cortex but strips or patches of irregular cortex occurred in contrast with irregular (haplo-diplo)-triplostichous isostichous cortexes of the holotype. This is the most significant difference.

2) Usually has a greater number of branchle segment including cells of the ecorticate segment, as in an individual segments described by R.D. Woo \& IMAHORI (7-8) and the corticated segments $(5,6)$ within it; their numbers sometimes correspond to those indicated in the diagnosis ( 6 and 4 ) or less ( 5 and $0-3$ )

3) More variable length of the end cell of a branchlet;

4) Greater number of branchlets in a whorl: 9-11 vs. $6-8(11$ ?);

5) Higher maximal absolute and relative value of internode length (up to $18.8 \mathrm{~cm}$ and 6.3-times longer than the branchlet);

6) Wider range of absolute and relative lengths of spine cells;

7) Presence of ecorticate branchlets with developed bract-cells at several basal nodes

8) Sometimes longer ecorticate segments;

9) The bract-cells can be smaller than in the holotype although they are fully developed an never rudimentary. This feature provides for habitual similarity with Lychnothamnus, but Lychnothamnus-like habit would be unusual for all populations of $C$. globata;

10) Higher maximal length of branchlets;

11) Variable degree of thallus incrustation, from almost un-incrusted to heavily incrusted;

12) Fewer number of oospore striae: $11-14$ vs. 15 ; 13) Basket-like protrusion formation on the basa pole of oospores.

The quantitative differences listed above (No 3-5, 
7-10) haven't hiatus with the holotype description and don't have primary taxono hical inportance at the species level. Moreover, some of these differences are known to be environmentally-dependent. In particular,
the variable absolute and relative lengths of internodes and branchlets may reflect light intensity (SCHNEIDER et al. 2006), while the degree of incrustation can reflect plant age, photosynthetic activity, calcium and carbonate ion concentrations, and $\mathrm{pH}$ and temperature of the habitat (Sмiтh 1985, cited by KawaHATA et al 2013).

The differences in taxonomically importan characteristic (No. 1) and presence of previously undescribed (No. 6, 12) or poorly described feature (No. 11) could be explained by the individual peculiarities of the holotype, including absence of ripe ospores. The discrepancy in cortex arrangement wa actually quantitative because the patches of the diplotriplostichous cortex were also presented in studied specimens; therefore, this difference was expressed in frequency of different patterns occurrence.

Another possible explanation of this inconsistency of stem cortex arrangement in a different distribution range is phenomenon that is well-known for $C$. tomentosa $\mathrm{L}$.; where different specimens have non-identical expression of this characteristic. They usually have a diplostichous cortex but specimens with a triplostichous cortex are also known (OLSEN 1944, TORN et al. 2003). Sometimes different cortex pattern may be observed in specimens from the same lake collected in different years (Romanov \& KIPRIYANOV 2010)

The specimens we studied better fitted the protologue (MIGULA 1904) than the later re-description (WOOD \& IMAHORI 1964, 1965) in several features (i.e., common type of stem cortex arrangement and number of branchlets in a whorl) but differed from protologue and re-descriptions, both in the usually greater number of branchlet segment and corticated segments within . The incomplete matching of other characteristic within the previous description might be regarded as intraspecific variability better represented in the studied collections. The oospore surface ornamentation had never been described for this species. Therefore, our description based on specimens outside of the locus classicus expands and improves the diagnosis of $C$. globata.

\section{Systematics}

C. globata was assigned to the section Grovesia Grovesia R.D. Wood (WoOD 1962, 1964; Wood \& IMAHORI 1965) and section Diplostephanae, series or subsection Triplostichae (HAN \& Li 1994; Ling et al. 2000). The macrospecies concept implemented by Wood in the taxonomic treatment of charophytes significantly reduced the number of species due to assigning many described species to varieties, forms, and synonyms (WoOD 1964;
Wood \& IмAновi 1965). Nevertheless, the species status of $C$. globata was retaned as a reflection of the prominent combinations of its characteristics (WooD \& IMAHORI 1965: 213)

The crossing experiments seemingly confirmed the sexual incompatibility of C. globularis-complex members (section Grovesia, subsection Grovesia) with C. zeylanica Willd. (section section Grovesia, subsection Willdenowia), C. vulgaris, C. contraria (section Chara, subsection Chara), and C. globat (PROCTOR 1971, 1975). In contrast, C. globata from Israel as well as a plant resembling $C$. domini $\mathrm{V}_{\mathrm{IL}}$ from Uzbekistan, crossed freely and reciprocally with plants of C. polyacantha A. BRAUN in A. BRAUN, RABenH. et StizenB. from Denmark. Hybrid offspring were vegetatively near normal but often wholly or partially self-sterile. Unfortunately, the collectio sites for these specimens were not published, however, according to the context and available data from labels of specimens stored in NY (http://sciweb.nybg.org Science2/vii2.asp), we may conclude that specimen from the quarry, Solomon's pools, and one locality from Central Sinai, had been used.

The mostly diplostichous stem cortex typica for studied specimens of $C$. globata is in contras with a main feature of species from the section Growesia, having a triplostichous cortex. Obviously, the assignment of $C$. globata to this section may reflect peculiarities of the holotype, which have bee discussed above. The morphological characters as well as negative results of breeding experiments poin towards erroneous placement of $C$. globata within this section. The cortex arrangement, solitary spine-cells only, and stipulodes in two tiers, all correspond well to the section Chara, subsection Chara sensu Woo (WOOD 1962; WOOD \& IMAHORI 1965). However, this was not supported by crossing experiments, which pointed toward an affinity of $C$. globata with species from subsection Hartmania (РRостоR 1971, 1975). Therefore, according to morphological characteristics and sexual compatibility, C. globata should be transferred to section Chara. The subsection placement is problematic and needs further investigation with better taxon sampling and likely additional molecular markers.

Phylogenetic affinity

Two C. globata accessions (Israel and Russia) have produced identical $r b c \mathrm{~L}$ sequences. Based on a dat set of 1.072 aligned characters (with 26 potentially parsimony-informative characters), C. globata wa resolved in a moderately supported clade $(82 \%)$ comprising members of the section Chara an subsections Hartmania and Chara (C. contraria). There it was placed as a sister ( $90 \%$ bootstrap, only 2 positions difference) to five species of sub-sectio Hartmania having identical sequences (Fig. 3). C.

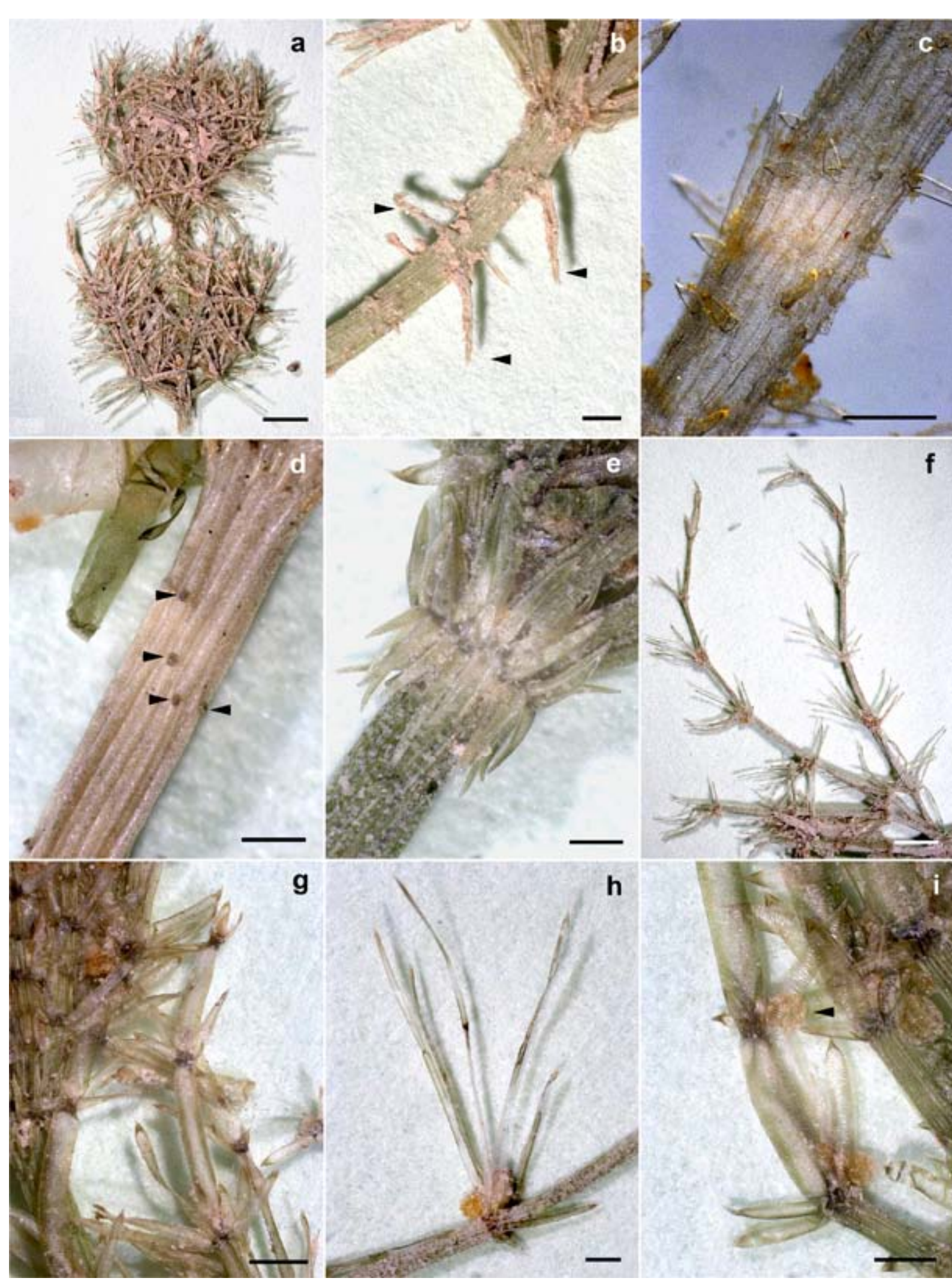

Fig. 1. Morphological characters of C. globata, LM: (a) whor of branchlets; (b-d) stem cortex (arrowheads indicate spine cells); (e) stipulodes segment of branchlet (arrowhead). Scale bar $0.5 \mathrm{~mm}$, exept (a) $2 \mathrm{~mm}$. 

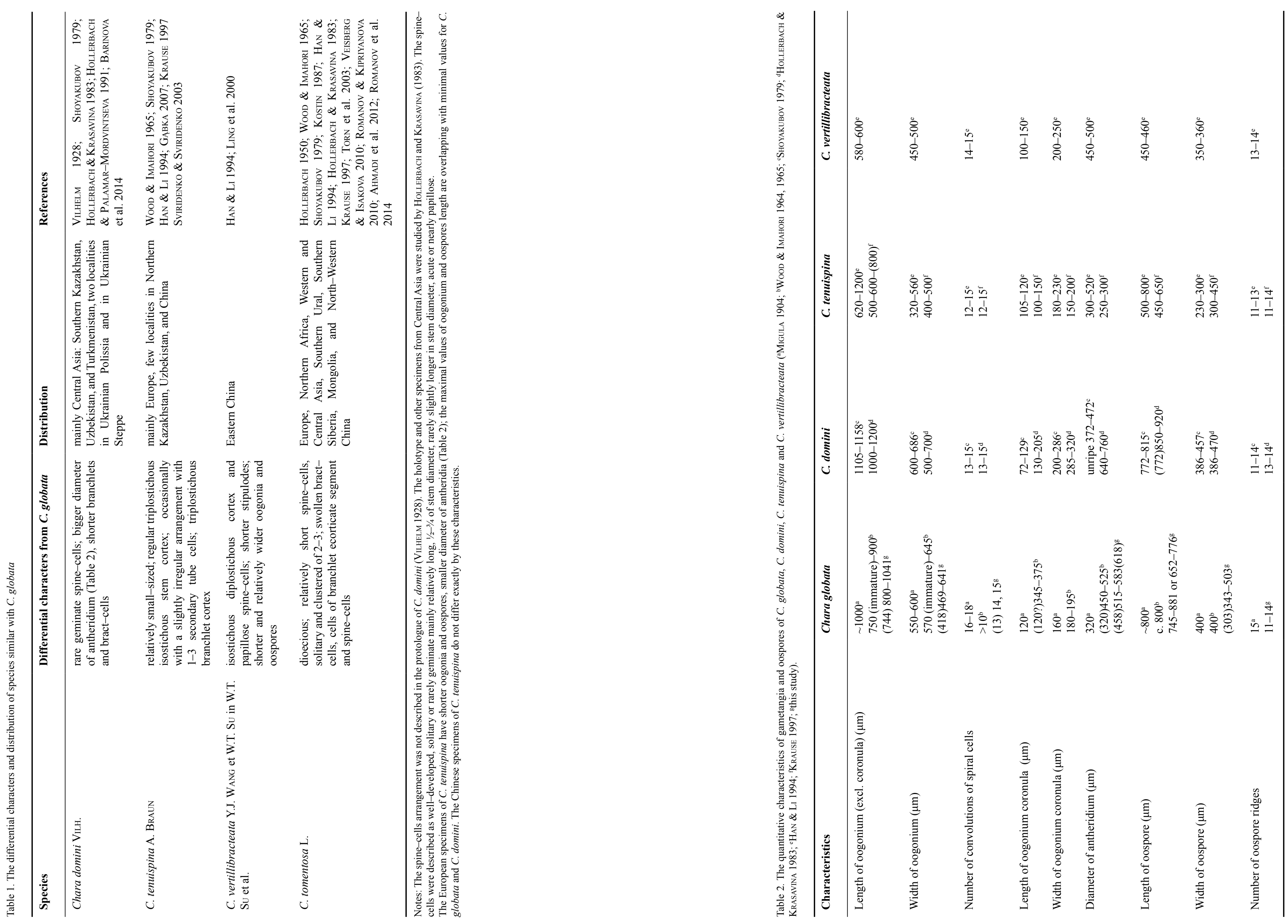
vulgaris and C. tomentosa, also members of the subsection Chara, showed only a distant relationship to C. globata and this lineage.

The results of our phylogenetic analysis generally corroborate conclusions based on phenotypic data and suggested that $C$. globata has no affinity to the section Growesia. Rather, the species shows a close relationship to the subsection Hartmania and to some members of the sub-section Chara (C. contraria), although not monophyletic in our analysis.

Similar species

C. domini $\mathrm{V}$ ILH. (the name follows protologue (VILHELM 1928), C. tenuispina A. Braun, C. vertillibracteata Y.J. WANG et W.T. Su in W.T. Su et al., and C. tomentosa are similar to C. globata in combinations of characteristics or general habit. We compared the description of ranges of these species and distribution range to outline the borders and distinctive characters of species similar to C. globata (Table 1). The other characteristics may be easily compared using a matrix key to the charophyte species (van RaAm 2009). By this approach $C$. domin is the most similar species. The specimens referred to as C. domini from Uzbekistan (SHOYAKuBov 1979) closely resembled the studied specimens of $C$. globata. Plants from Uzbekistan differed by bushy habit, regular diplostichous tylacanthous stem cortex only, fewer branchlets in a whorl (7), higher upper values of the number of corticate segments (7), length and width of oogonia (1158 and $686 \mu \mathrm{m}$ ), length of oospore ( 815 $\mu \mathrm{m})$, and thick lime-shell of oospore. Therefore, these specimens were more similar to $C$. globata than $C$. domini, and possibly with several other records of $C$ domini. Therefore, C. globata is possibly conspecific with $C$. domini and in this case the first name would have priority but this conclusion should be validated by study of numerous specimens of C. domini, including the type specimens.

\section{Distribution of $C$. globata}

C. globata was first described from Beijing (Peking) based on a collection of E. BRETSCHNEIDER made in 1877 (LE; Migula 1904; Wood \& IMAhori 1965). The characteristics of the locus classicus are unknown, including the type of water body (LE; MIGULA 1904). The collections of BRETSCHNEIDER were mostly taken from the northwest vicinity of Beijing and within the city (BRETSCHNEIDER 1898).

C. globata was reported for China not only from locus classicus but also from arid and semiaric regions (i.e., from one locality in Gansu and three localities in Xinjiang Uyghur Autonomous Region; HAN \& Li 1994; Ling et al. 2000). It is also known from Yunnan (Deng \& Zhang 1996). We believe this species also be listed in several other inaccessible Chinese articles. The recent photo of a specimen very similar to $C$. globata was posted at a forum on September 25, 2009 (http://www.planta.cn/forum/viewtopic php?t=18248\&view=previous; Image DSCF1475. JPG). It had been collected within Eryuan County (Ëryuán Xiàn) in the Dali Bai Autonomous Prefecture located on the south of Yunnan.

The origin of living plants of $C$. globata used fo breeding experiments was not reported (PROCTOR 1971, 1975), but according to the context and the labels of the specimens studied, Israel might have been the locality used (see list of localities above). A strain of C. globata identified by Y. LIPKIN was isolated from the Mamilla Pool in Jerusalem (reported with erroneous spelling as C. globate; MiLner \& AvigAD 1972). Unfortunately, latter records were not consistent with herbariun specimens used in TELA and could not be verified. Although this water body still exists, it is currently inaccessible. If this population could be found it would likely be useful for future studies.

C. globata was also found in Lake Balkhas in southern Kazakhstan and in the delta of lli Rive, before and at the initial stages of its damming, and also in water bodies that had disappeared within the flooding area of the Qapshaghay Bogeni Reservoir, also known as the Kapchagay Reservoir (reported with erroneous spelling as C. globosa Migula in several cases; Kosti \& Shоуакuвov 1972, 1973a,b, 1974a,b; Sноуакиво 1973, 1979). Subsequently, C. globata has not been listed among the species found there (KosTin 1987). Therefore, these findings require confirmation, but the presence of C. globata in south of central Asia remain possible.

All records, except for the first diagnosis an holotype re-examination refer to species name only and were not accompanied with locality and specimens' description and illustrations. The description and figures in "Flora Algarum Sinicarum Aquae-Dulcis" (HAN \& LI 1994: 235, 236, fig. 182) repeated those in "A revision of the Characeae" (Wood \& IMAHORI 1964 Icone 87; 1965: 213)

Our study confirmed the presence of this species in western Asia (for details see Supplement S2), the eastern Mediterranean (Israel), and extended its distribution range to Europe (Russia, Krasnodar Oblast) and the Sahara-Arabian desert region (Egypt, Sinai). The new records reflect the rather poor knowledge on charophytes diversity in southeastern Europe and the Sinai Peninsula and could not be assessed as invasio cases.

C. globata has been referred to as a temperate species (DENG \& ZHANG 1996). All data available o its distribution are summarized in Figure 4. Notably, a recent intensive study on Iranian charophytes did not reveal this distinct species (AHMADI et al. 2012). It might be concluded that $C$. globata has a disjunctive distribution with two main parts in arid and semi-arid regions of Central Asia and the Eastern Mediterranean.

Ecology

C. globata has been found in pools and lakes (KostiN

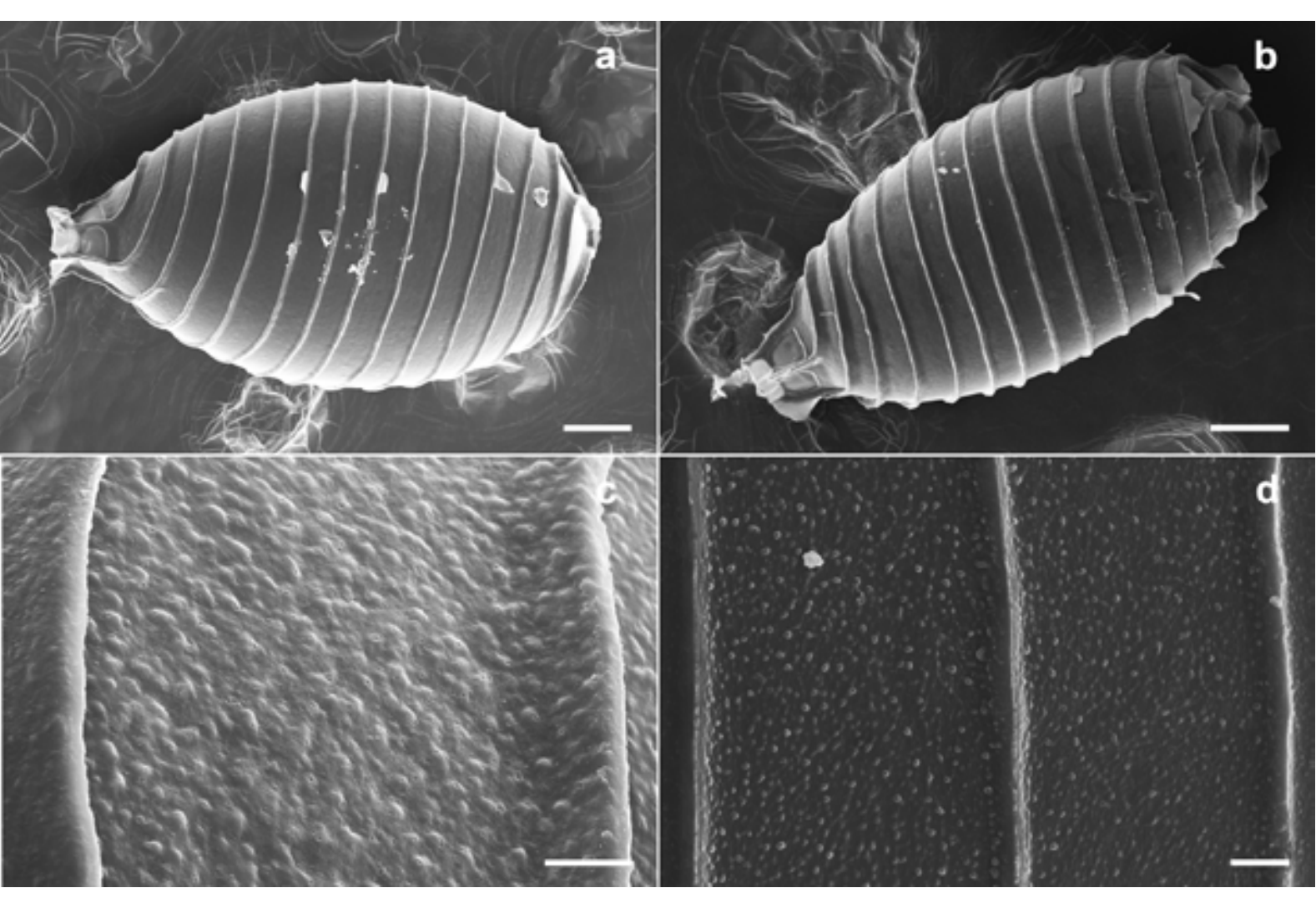

Fig. 2. The oospores of $C$. globata, SEM. Scale bar $100 \mu \mathrm{m}$, exept (c, d) $10 \mu \mathrm{m}$.

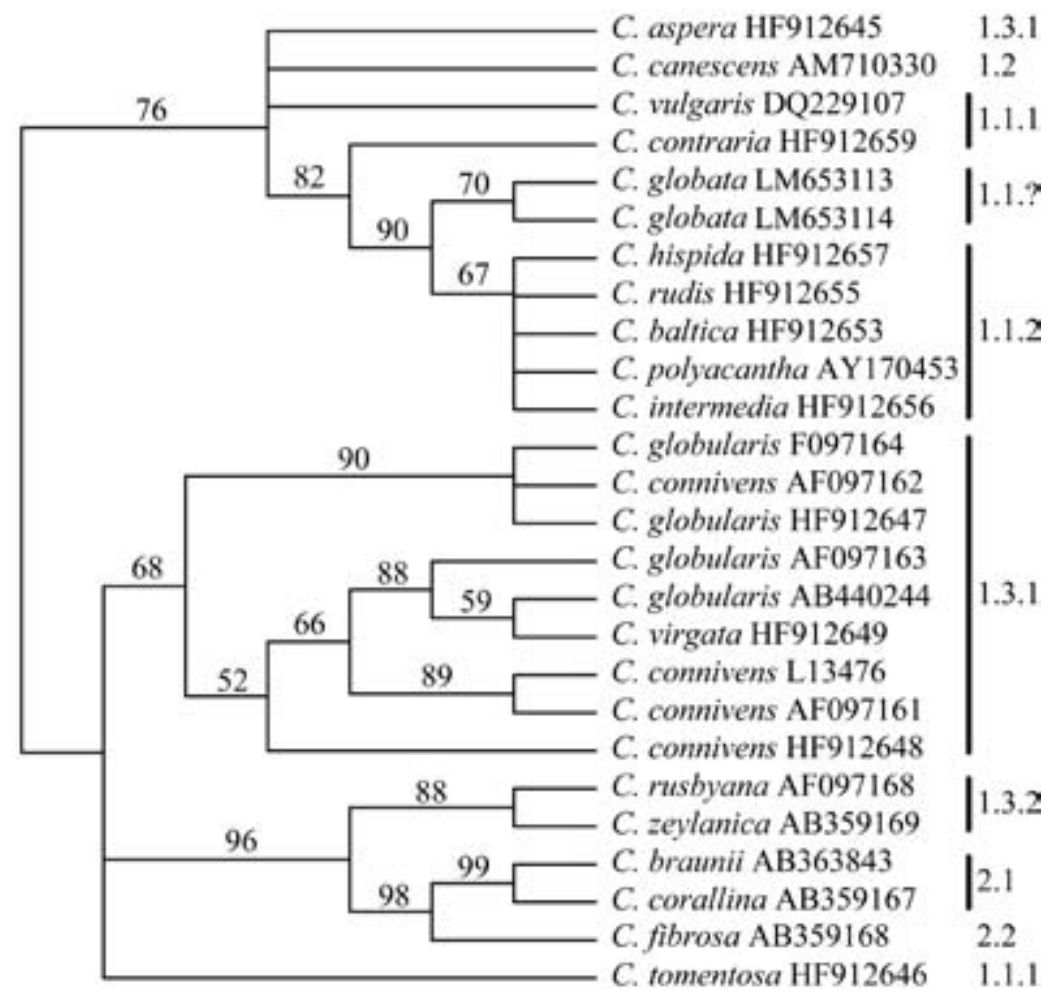

Fig. 3. MP phylogenetic tree based on 1072 aligned characters (26 MP-parsimony-informative) showing affinity of $C$. globata. Numbers
above branches are bootstrap percentages $($ (1) subgenera Chara R.D. Woop (1.1.) section Chara R.D. Woop, (1.1.1) subsection Chara R.D. Wood, (1.1.2) subsection Hartmania R.D. Wood, (1.2) section Desvauxia R.D. Wood, (1.3) section Grovesia R.D. Wooo, (1.3.2) subsection Willdenowia R.D. Woop; (2) subgenera Charopsis R.D. Woop: (2.1) section Charopsis R.D. Woon,
(2.2) section Agardhia R.D. Woop]. 
\& ShоуакUвоv 1973a; 1974a,b; Ling et al. 2000), including deep pools on groundwater outputs and oxbow lake (this study), uncovered rainwater reservoirs (MILNER \& Avigad 1972; this study), and an inundated quarry (this study). These water bodies are situated mainly in arid and semiarid regions (i.e., in desert, steppe, and Mediterranean regions).

The environmental requirements of $C$. globata requires further study and description. According to published records, it has been found at a depth up to $2 \mathrm{~m}$ within a salinity range of $1.481-2.330 \mathrm{~g} . \mathrm{dm}^{-3}$ (Kostin \& Shoyakubov 1973a, 1974a,b). The species was successfully cultivated in an aqueous solution of water extract of soil containing sodium carbonate $(20 \mathrm{ppm})$ and calcium carbonate $(50 \mathrm{ppm})$. During cultivation, the $\mathrm{pH}$ of the media increased from 7.5 to 8.5 ; at a higher level (9 and more) the growth of C. globata was poor (Milner \& Avigad 1972). Unfortunately, these records are not verifiable due to the absence of description, illustrations, and existence of voucher specimens. We can therefore conclude that $C$. globata could be a fresh-brackish moderately alkaliphilic species which prefers to grow in water containing predominately sodium sulfate, calcium, and magnesium bicarbonate. Therefore, we can preliminarily classify the environment of $C$. globata as arid-semiarid, with high insolation and middleto-high range of water temperature all year around,

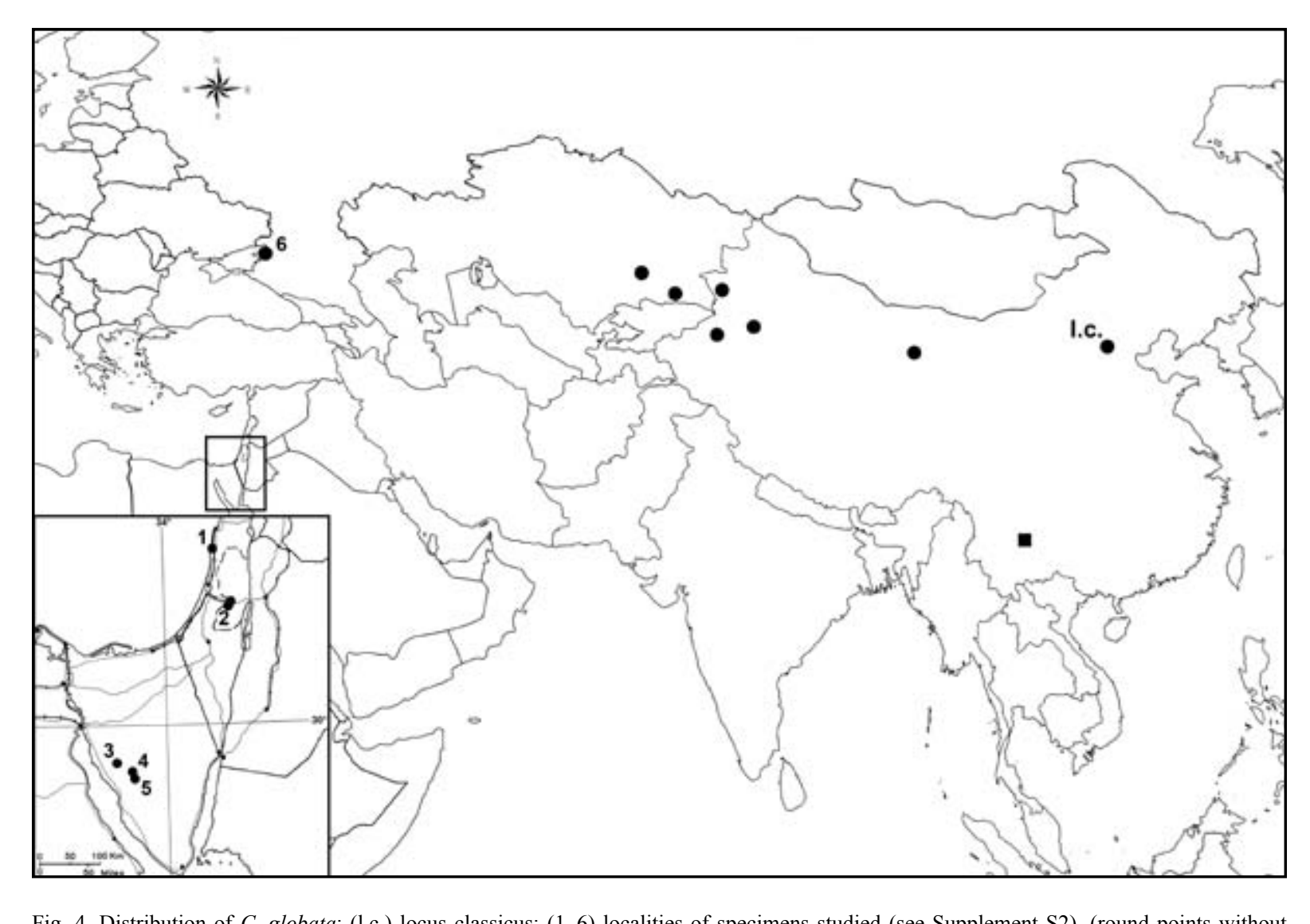

Fig. 4. Distribution of C. globata: (1.c.) locus classicus; (1-6) localities of specimens studied (see Supplement S2), (round points withou

Fig. 4. Distribution of $C$. globata: (1.c.) locus classicus; (1-6)
number) localities reported, (quadrate) exact locality unknown.

with middle-to-high class of salinity according to ollute nitrate concentrations (i.e. water quality class III-IV (BARINOVA 2011).

ACKNOWLEDGEMENTS

The authors thank Marcelo Sternberg, Ludmila N. Voloshko and specimens (TELA, LE), Andrey N. Lubchenko for specimen collected and for permission to use his excellent photos of liv

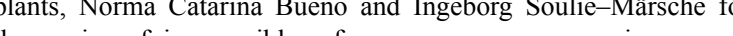
the copies of inaccessible references, anonymous reviewers an
editor-in-chief of Fottea Aloisie Poul'̌̌k ková for their very helpful suggestions. This material is based upon work supported by the Israel Taxonomy Initiative, Russian Foundation for Basic Research Absorption of Israel.

\section{ReFERENCES}

Hmadi, A.; Riahi, H.; Sheidal, M. \& van RaAm, J. (2012): Some charophytes (Characeae, Charophyta) from kohrangiana species nova - Cryptogamie, Algologio 33: 359-390.

Barinova, S. (2011): Algal diversity dynamics, ecologica assessment, and monitoring in the river ecosystems
of the eastern Mediterranean. - 363 pp., Nova
Science Publishers, New York, USA

Barinova, S.; Fatyukha, A. \& Romanov, R. (2014) Macrophytes and Charophyceen Algae in Ecologica Assessment of the protected lakes in Donetsk region press).

Bıcudo, R.M.T. (1976): Chara linharensis, uma nova espécie de Characeae do sudes
Cultura 28: 1314-1318.

BRETSCHNEIDER, E. (1898): History of European botanical discoveries in China II. - pp. 625-1167, Sampson Low, Marston and Co, London.

Brimacombe, J.S.; FerRIER, R.J.; Guthrie, R.D.; Inch, T.D. KENNEDY, J.F. \& STURGEON, R.J. (1973): Specialis A review of the Literature published during 1972. 492 pp., The Chemical Society, London.

Deng, X. \& Zhang, W. (1996): Studies on the Charophytes from Yunnan Province, China. - Journal of Yunnan University 18: 135-138. [in Chinese.

Eсht, C.S.; ERDAHL, L.A. \& McCoy, T.J. (1992): Genetic segregation of random amplified polymorphic DNA

FOISSER, W. (2006): Biogeography and dispersal of microreview emphasizing protists. - Acta Protozoologica 45: 111-136.

Folssner, W.; ChaO, A. \& Katz, L.A. (2008): Diversity and geographic distribution of ciliates (Protista: Ciliophora). - Biodiversity and Conservation 17 $345-363$.

FRAME, P.W. (1974): Unusual branchlet development in the genus Chara L. (Charophyta). - Botanical Journal of

GABKA, M. (2007): Distribution of Chara tenuispina A. Braun 1835 (Characeae) in Poland. - Oceanologica Galtier, N.; GouY, M. \& Gautier, C. (1996) Seaview and phylo-win: two graphic tools for sequence
alignment and molecular phylogeny. - Comput Appl alignment and molecular phylogeny. - Comput App Biosciences 12: 543-548

HAN, F.S. \& LI, Y.Y. (eds) (1994): Flora algarum sinicarum aquae dulcis. Tomus 3. Charophyta / Consilio Sinicae edita. - 267 pp.. Science Press, Beijing. [in Chinese].

Hollerbach, M.M. (1950): The systematic list of charophytes, found on USSR territory till 1935 inclusively. - Proceedings of Botanical Institute of Academy of Sciences of USSR. Series II: 20-94. [i Russian.

Hollerbach, M.M. \& Krasavina, L.K. (1983): The 14 The char Leningrad. [in Russian].

Hollerbach, M.M. \& Palamar-Mordvintseva, G.M. (1991): The identification manual of freshwater algae of Ukraine 9. The charophytes (Charophyta). - 196 pp., Naukova dumka, Kyiv. [in Ukrainian].

Husted, F. (1957): Die Diatomeenflora des Fluss-system der Weser im Gebiet der Hansestadt Bremen. zu Bremen 34: 181-440, $1 \mathrm{pl}$

Kawahata, C.; Yamamuro, M. \& Shiraiwa, Y. (2013): Changes in alkaline band formation and calcification of corticated charophyte Chara globularis. - Springer
Plus 2: 85.

KhaN, M. \& SARMA, Y.S.R.K. (1984): Cytogeography an cytosystematics of Charophyta. - In: IRvine, D.E.G.

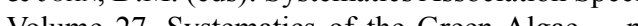
303-330, Academic Press, London -Orlando - Sp Diego - New York - Toronto - Montreal - Sydney - Tokyo.

Kiselev, K.V.; Shumakova, O.A. \& TCHerNoded, G.K. (2011): Mutation of Panax ginseng genes during long-tern cultivation of ginseng cell cultures. - Journal of Plan

Kostin, V.A. (1987): Materials for the study of ecology of charophytes in water bodies if the Ili-Balkhas
drainage basin. - Botaničeskie Materialy Gerbarij Instituta botaniki Akademii nauk Kazahskoj SSR 15 : 128-133. [in Russian].

Kostin, V.A. \& SHOYAKuBOV, R.SH. (1972): Charophytes of water bodies of Ili delta. - In: Abstracts of IV Transcaucasian conference on cryptogamous plants.

-pp. 26-29, Erevan. [in Russian].
Kostin, V.A. \& SHoYakuBov, R.SH. (1973a): Charophytes of the Lake Balkhash and influence of severa and physiology of microorganisms, algae and aquatic plants: Proceedings of conference of young scientists, 5-7th Febuary 1972. - pp. 166-170, Fan, Tashkent. [in Russian].

Kostin, V.A. \& ShoyakuBov, R.Sн. (1973b): Charophytes of water bodies in flooding area of the Kapchaga reservoir (on the Ili River), their distribution and
ecology - In: Charophyta algae and their use in ecology. - In: Charophyta algae and their use in
the investigation of the biological processes of the cellule (The Material for All-Union symposiuns on the investigation of Charophyta algae, Vilnius, September 27, 1973). - pp. 88-94, 439, Vilnius. [in Russian].

Kostin, V.A. \& ShoYakubov, R.SH. (1974a): Charophytes of the Lake Balkhash and influence of several ecological Algas and fing of Central Asia 1. The 12-16, F.) Algae and fungi of Central Asia 1. - pp. 12-16, Fan

Tashkent. [in Russian].
Kostin, V.A. \& SHorakuBov, R.SH. (1974b): Distribution and biomass of charophytes in Lake Balkhash. - In: Fifth and Kazakhstan. 26-27点 April 1974. Abstracts (firs part). - pp. 182-183, Ashkhabad. [in Russian].

LI, Y. (1985): Some new taxa and records of Charaphyt [Charophyta] in China. - Oceanologia and

Ling, Y.; XIE, SH. \& LanGAnGeN, A. (2000): Charales of CRT, JR. (1994): Phylogenetic analy

genetic analysis of green plant Evolution 3: 114-127.

Migula, W. (1904): Characeae Rossicae ex herbario Hor Petropolitani, determinatae et descriptae a prof. W. Migula (Karlsruhe). Acta Horth Petropolitani 23 :

MiLner, Y. \& AVIGAD, G. (1972): Preparation of ${ }^{14} \mathrm{C}$ labeled pectic acid and D-galacturonic- ${ }^{14} \mathrm{C}$ acid.

OLSEN, S. (1944): Danish Charophyta S. Cogical and biological investigations - Kongelige Danske Videnskabernes Selskab. Biologiske Skrifter 
3. -240 pp., København.

Proctor, V.W. (1971): Chara globularis Thuillier (= C. fragilis Desvaux): breeding patterns within a cosmopolitan complex. - Limnology and Oceanography 16: 422-436.

Proctor, V.W. (1975): The nature of charophyte species. Phycologia 14: 97-113.

Romanov, R.E. \& Barinova, S.S. (2012): The charophytes of Israel: historical and contemporary species richness, distribution, and ecology. - Biodiversity Research and Conservation 25: 67-74.

Romanov, R.E. \& Kipriyanova L.M. (2010): Charophyte species diversity and distribution on the south of the West-Siberian Plain. - Charophytes 2: 72-86.

Romanov, R.E.; ZhaKova, L.V.; Bazarova, B.B. \& KIPRIYANOVA, L.M. (2014): The charophytes (Charales, Charophyceae) of Mongolia: a checklist and synopsis of localities, including new records. Nova Hedwigia 98: 127-150.

Schneider, S.; Ziegler, C. \& Melzer, A. (2006): Growth towards light as an adaptation to high light conditions in Chara branches. - New Phytologist 172: 83-91.

ShoYaKubov, R.SH. (1973): The analysis of charophyte flora of Central Asia. -In: Charophyta algae and their use in the investigation of the biological processes of the cellule (The Material for All-Union symposium on the investigation of Charophyta algae, Vilnius, September 27, 1973). - pp. 75-82, 438, Vilnius. [in Russian].

Shoyakubov, R.Sh. (1979): Charophytes of Uzbekistan. 156 pp., Fan, Tashkent. [in Russian].

SмITH, F.A. (1985): Biological occurrence and importance of $\mathrm{HCO}_{3}$ - utilizing systems: macroalgae (Charophytes). - In: LuCAS, W.J. \& BerRY, J.A. (eds): Inorganic carbon uptake by aquatic photosynthetic organisms. - pp. 111-124, American Society of Plant Physiologists, Maryland.

SOULIE-Märsche, I. (1989): Etude comparée de gyrogonites de charophytes actuelles et fossiles et phylogénie des genres actuels. (Thèse-ès-Sci. Univ. Montpellier 1979, rev. edit.). - 237 pp., Impr. des Tilleuls, Millau.

Sviridenko, B.F. \& SviridenKo, T.V. (2003): Distribution and ecology of Charophyta in the Northern Kazakhstan. Acta Micropalaeontologica Sinica 20: 139-146.

Swofford, D.L. (2002): PAUP*. Phylogenetic Analysis Using Parsimony (*and other methods). Version 4. Sinauer Associates, Sunderland, USA.

Su, W.T.; WANG, Z.X. \& WANG, Y.J. (1990): Some new taxa of Charophyta in China. - Acta Phytotaxonomica Sinica 28: 333-340. [in Chinese].

Torn, K.; Georg, M. \& Munsterhjelm, R. (2003): Chara tomentosa L. 1753. - In: Schubert, H. \& Blindow, I. (eds): Charophytes of the Baltic Sea. - pp. 131-141, Gantner Verlag, Ruggell, Liechtenstein.

TYler, P.A. (1996): Endemism in freshwater algae with special reference to the Australian region. Hydrobiologia 336: 1-9.

URBAnIAK, J. (2011): A SEM and light microscopy study of the oospore wall ornamentation in Polish charophytes (Charales, Charophyceae) - genus Chara. - Nova Hedwigia 93: 1-28.

VAN RAAM, J. (2009): A matrix key for the determination of Characeae. -Rostocker Meeresbiologische Beiträge 22: $53-55$.

Veisberg, E.I. \& Isakova, N.A. (2010): Species composition of Charophyta in the Chelyabinsk region waterbodies. - Botanicheskij Zhurnal 95: 1437-1443. [in Russian].

Vilhelm, J. (1928): Characeae Europae Orientalis et Asiae ex Herbario Instituti Cryptogamici Horti Botanici Reipublicae Rossicae (ante Petropolitani). - Spisy vydávané Prŕrodovědecheskou Fakultou Karlovy University 80: 1-24.

Wood, R.D. (1952): The Characeae, 1951. - Botanical Review 18: 317-353.

Wood, R.D. (1959): Constants of extant Charophyta for use in micropaleobotany. - Journal of Paleontology 33: 186-194.

Wood, R.D. (1964): A synopsis of the Characeae. - Bulletin of the Torrey Botanical Club. 91: 35-46.

Wood, R.D. (1962): New combinations and taxa in the revision of Characeae. - Taxon 11: 7-25.

WoOD, R.D. \& IмAноRI, K. (1959): Geographical distribution of Characeae. - Bulletin of the Torrey Botanical Club 86: $172-183$.

WoOd, R.D. \& IMAHORI, K. (1964): A revision of the Characeae. II. Iconograph of the Characeae. $-\mathrm{v}-\mathrm{xv}$ +5 pp., 1-395 icons, J. Cramer, Weinheim.

WoOd, R.D. \& IMAHORI, K. (1965): A revision of the Characeae. I. Monograph of the Characeae. - i-xxiv + 904 pp., J. Cramer, Weinheim.

Supplementary material

the following supplementary material is available for this article:

S1. Complete morphological description of specimens studied.

S2. Description of localities in Western Asia and SouthEastern Europe.

This material is available as part of the online article (http://fottea.czechphycology.cz/contents)

(C) Czech Phycological Society (2015)

Received August 12, 2014

Accepted November 10, 2014 